\title{
Analysis of concepts of cadastral system technological development
}

\author{
Agnieszka Dawidowicz, Ryszard Źróbek \\ University of Warmia and Mazury in Olsztyn, Faculty of Geodesy and Land Management, \\ Department of Real Estate Resources, Oczapowskiego 2, Olsztyn 10-719, Poland
}

\begin{abstract}
The dynamic development of modern information technology (IT) directly affects the development of cadastral systems. These specialized information systems should adapt modern technical and technological solutions arising from the operational requirements of their functionality. Technological progress also relates surveying instruments and geodesy methods of measurement and analyzes of data in the field.

The paper presents proposals of the cadastral system modernization in the technology development aspect, which have appeared in the international scientific forum since paradigm "Cadastre 2014".

Authors have determined the direction of cadastre development in the context of technology evolution.
\end{abstract}

Keywords: cadastral systems; information technology (IT); standardization.

\section{Introduction}

The development of cadastral system was and still is determined by the dynamics of the growth needs of globalization, including changes of many factors such as: the development of spatial information technology (IT), development of the theory of sustainable space development, intensity of natural phenomena and the economic need for 3D/4D visualization in real time, the desire to data standardization / normalization and the interoperability of the systems [1].

Particular attention should be given to the dynamics of the multiple systems technological modernization due to the creation of advanced information technology (IT) arising with the trend of globalization.

An important feature of globalization was to create a global information system, whose main link is the connection global network and especially the Internet system providing comprehensive ability to communicate. Development of the Internet is also possible to access to a wide range of geospatial information, including cadastral information.

This phenomenon has been the subject of extensive scientific analysis, of which it is worth emphasizing the position of Williamson [2]. The author has identified five stages in the evolution of the cadastral system from the perspective of technology development, see Figure 1.

1970

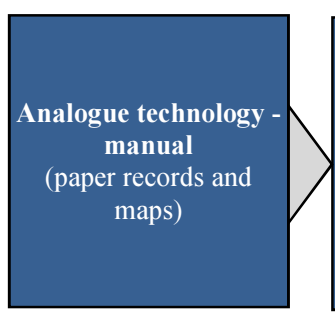

1980

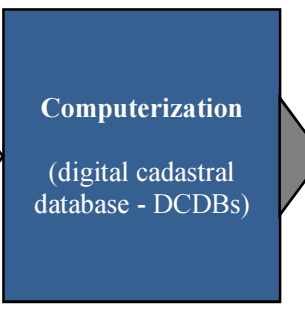

1990

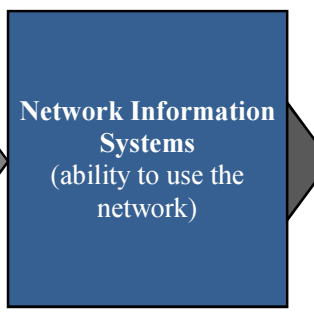

2005

2010

Fig. 1. Technological evolution of cadastral system. Source: own study based on Williamson [2]

Corresponding author: Agnieszka Dawidowicz. E-mail address: agnieszka.dawidowicz@uwm.edu.pl

http://dx.doi.org/10.3846/enviro.2014.201

(C) 2014 The Authors. Published by VGTU Press. This is an open-access article distributed under the terms of the Creative Commons Attribution License, which permits unrestricted use, distribution, and reproduction in any medium, provided the original author and source are credited. 
In the years 1970-1980 cadastral systems were carried out through the "historical" - paper maps and records. At this stage, the role of the cadastre focused on protecting ownership during the land sales. Since 1980 has began the computerization of these records and the creation of digital cadastral databases (DCDBs).

Computerization has been a catalyst of organizational and institutional changes of cadastral systems where operating before separately surveying, cartography (maps), cadastre and land registers have begun to function together. Integrated cadastral systems have gained in importance.

Along with the development of the Internet in 1990-2000 appeared the possibility of cadastral data sharing on a network, so that the system has become focused on the provision of information services. This situation opened the way for other institutions to share their spatial data that had not been in the cadastral database resources. Consequently was established a concept of creating Spatial Information Infrastructure (SDI) [3]. Cadastre has given a new role of reference register for other registers integrated in the spatial information infrastructure (basic references registry).

Since 2010, according to Bennett et al. [4], the cadastral and other spatial data integrated into SDI provide new opportunities thanks to the free processing of these data by both the public and private sectors. Therefore, the system can be used for new purposes such as environmental protection, business processes - investment, elective, emergency (crisis), and even in the fight against terrorism.

Presented in the diagram (Fig. 1) stages of the cadastre development summarize and direct its importance from the point of view of technological development. However, it is well known, that not all cadastral systems in the world reached described developmental stages in the specified time using identical tools. Individual countries systematically incorporate into their systems other technologies depend on internal needs and financial capabilities.

It is important to answer the question: Is there a tendency to aim for a common, standardized benchmarks in terms of technology and what is the dynamics of the cadastral systems new concepts formation and functional requirements.

For this purpose, have been analyzed important research and conceptual studies established on the international and Polish forum from the paradigm of "Cadastre 2014" [5]. The report, adopted by the General Assembly of the International Federation of Geodesy (FIG) still is an innovative studies in the field of cadastral systems development and is a reference document for the relevant research papers in the cadastre discipline.

\section{Research methodology}

Authors adopted for the analysis specific theoretical proposals and guidelines, which were chosen after a thorough analysis of the information contained in the various documents, such as: FIG publications, Commission Working Party on Land Administration, United Nations Economic Commission for Europe, World Bank, EuroGeographics, information published on the websites: www.fig.net, www.unece.org/env/wpla, www.world-bank.org/landpolicy, as well as publications in the conference proceedings and other studies included doctoral and habilitation thesis.

For the purposes of this study used a method for the analysis of similarity models [6], which determines what parameters (so-called similarity parameters) characterizing the systems determine the model system can be assumed that the model results could be transferred to the real system.

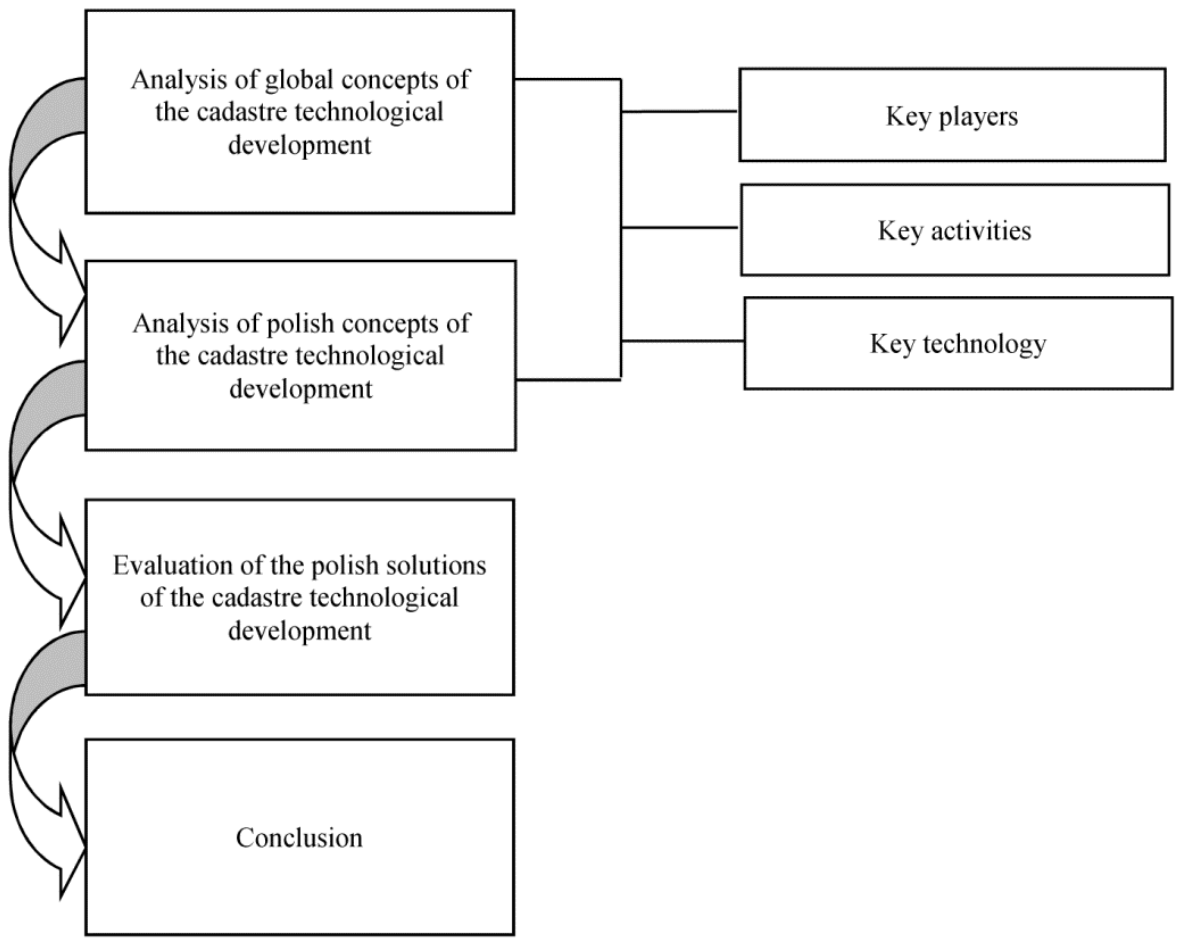

Fig. 2. Study organization diagram. Source: prepared by the authors. 
Analysis of the concept within the technology of cadastral systems conducting include the following information:

- Technological variants of acquiring spatial data and degree of process automation,

- Hardware and software for data processing,

- The level of the spatial data integration,

- Update processes and data quality control.

From a comparison of the listed objectives and indicators of the system in terms of technological development have been identified elements of convergences and divergences, on this basis singled dominant determinants, with the largest number of indications and additions, nonexclusive.

The analysis made it possible in particular to determine the dynamics of solutions to create a global model of the cadastre in the context of technological and to award trends in the study and evaluation of Polish proposals for worldwide projects.

The study includes a number of key issues outlined in the diagram, see Figure 2.

\section{Analysis of the cadastral system technological development concepts}

Clear and reliable analysis required transparent overview in the special layout in chronological order. For this purpose, the authors have adopted the tabulation approach (Table 1).

Table 1. International and Polish concepts of the cadastre technological development.

International concepts

$1998 \quad$ Cadastre 2014 [5]

2003

Cadastres after 2014 [7]

2003-2008 Core Cadastral Domain Model (CCDM) [8], [9], [10], [6], Land Administration Domain Model (LADM) [11]

Guidelines on real property units and identifiers [12], [13]. Land administration in the UNECE region [14].

EuroGeographics' Vision on Cadastre and Land Registration in Europe 2012 [15]

New directions for the Cadastre 2014 [16], [17], [18]
1) Geomatics technology.

2) Computer programs to support the cadastre should use the technique of defining data compilation and automatic formats generation.

3) geographic information is transmitted through "data highway".

4) The Internet and global data networks play an important role in the exchange of cadastral data.

1) Cadastre as a system of numerical databases.

2) The use of Internet technology to access to national and international data on-line using a single window.

3) E-data transfer

1) Advanced information technology (without the availability of information systems will be difficult to ensure accurate mapping towards fulfillment changing requirements of users).

2) Easy to change the dimension format of spatial data visualization, from $2 \mathrm{D}$ to $3 \mathrm{D}$

1) Information technology to conduct the cadastre, electronic data processing

2) Good practice in the implementation of information technology should:

a) provide easy public and private access to all data that are important and relate to the ownership, value and use of land, through linked computer networks;

b) Contain metadata that describe the land administration data in a clear and precise way (what data are available, their format, how to relate to other data, data quality, etc.). Such metadata should be stored in accordance with international standards;

c) Establish standards for transferring data from one system to another;

d) Include techniques such as the use of electronic signatures, in order to ensure that the transactions cannot be intercepted or modified by third parties.

1) Information technology to provide cutting-edge services for handling the real estate market and the land market.

2) The data on cadastral and property rights should be part of a national spatial data infrastructure, should be fully harmonized for data, metadata and services exchange at various levels and between various sectors.

1) The use of network technology (Internet) to exchange data.

1) High accuracy and timeliness of data visualized in 3D - 4D ( three-dimensional space depicted in real time)

2) Cadastres should be the foundation of Spatial Data Infrastructures (SDI)

3) Standard data writing in the object form that allows any mobile spatial analysis also using OpenGIS services.

4) Modeling generated through simple applications that will be made available to interested users via the Internet and mobile devices (eg: smartphones, tablets) and other media.

5) Cadastre in Cloud Computing - paradigm of cadastral data processing, saying that the processing capabilities will emerge from the economic justification and not the technical limitations [21], the type of processing based on the Internet, where shared resources, software and information are provided to computers and other devices on demand, like electricity. 
Continue of Table 1

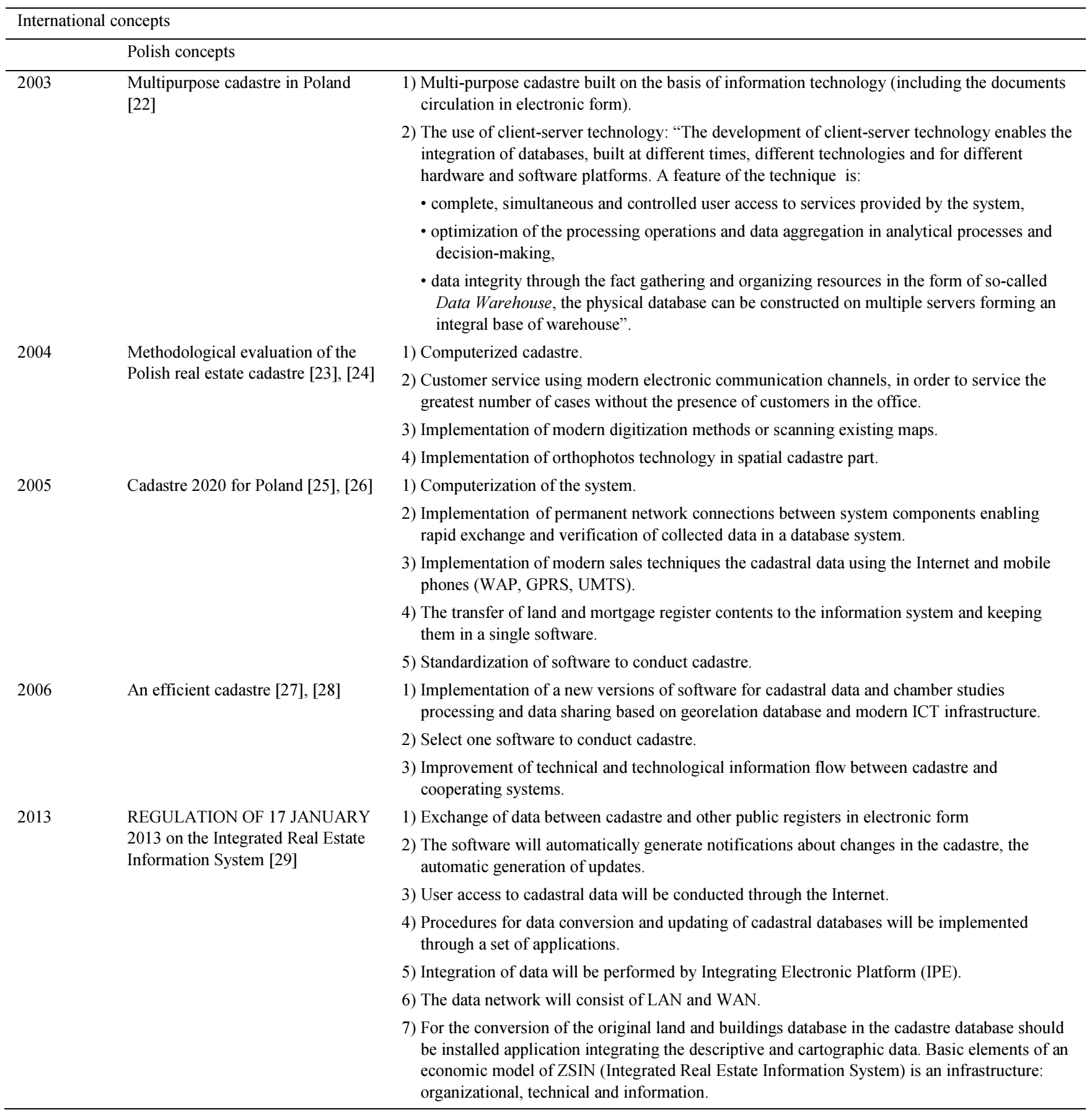

Source: own study.

Analysis of these studies allowed us to conclude that the "model" global cadastre should be computerized. Information technology should be used at all levels functioning of the system from data collection and flow through the exchange of data between spatial information systems, up to their share, see Figure 3.

Therefore, modern technology should also be used for geodetic measurement techniques [30], (GPS positioning system, the techniques of photogrammetry, remote sensing, the use of automatic theodolites).

Advantages of the use of digital databases are emphasized by all the analyzed studies. There were also in the report Cadastre 2014 published in 1998. This document contains references to the need to replace (sharing) of cadastral data via the Internet. In connection with such a demand since 1990 have been designed national spatial data infrastructure in the United States in 2001 initiated the construction of European spatial data infrastructure. Then were created the foundations of INSPIRE (Infrastructure for Spatial Information in the European Community), which in 2007 were adopted as Directive 2007/2/EC INSPIRE [31] by the European Parliament and the Council of the Commission of the European Community. 


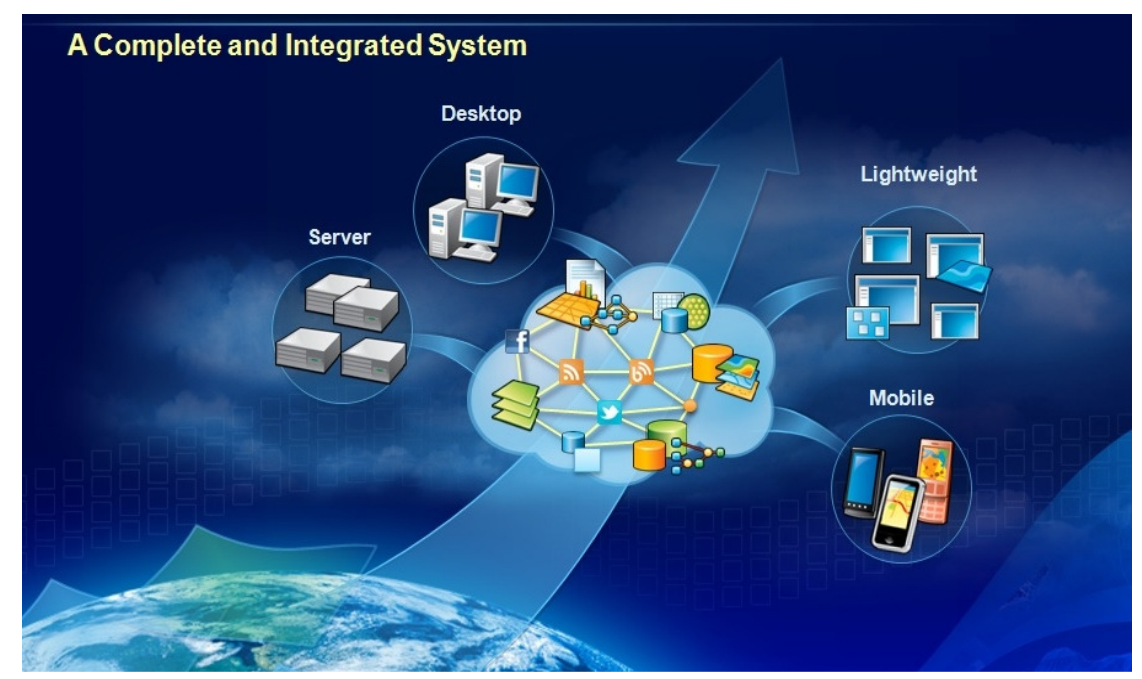

Fig. 1. The vision of global cadastre by the concept of Cadastre 2.0. [19]

Directive in its assumptions unified rules for storage and sharing of data and related services by the State authorities in Europe, public authorities and these private bodies which have decided to share their resources in accordance with the guidelines of the INSPIRE. Thus, since 2008 in many international and Polish studies have been frequent mentions the inclusion of cadastre to ICT infrastructure for spatial information (SDI).

The potential of information technology (IT) enables to develop solutions that operate efficiently and reliably. Only by using these technologies it is possible to design and implement clear and simple cadastral numerical models.

GIS technology is already at a high level and still grows at a rapid tempo in order to catch the customer, therefore creates a more modern solutions such as:

a) CAD-GIS (to create, maintain, analyze, present and plotting maps),

b) Compact GIS (stores in the same database simultaneously the object geometries with the assigned to it descriptive attributes, enabling the extraction and visualization of information from previously unimaginable speed),

c) Internet GIS (enables interoperability),

d) Multimedia GIS (combining video, audio, computer graphics and text)

e) Telegeoprocesing (enables the integration of spatial data from systems such as telecommunications and radio

communications, GPS location systems and monitoring systems),

f) Open GIS (stands for Open GIS, enabling the use of GIS data through the network regardless of the type of software, which have different users) [32].

All studies agree on the desirability of the modern GIS technology use for data exchange. GIS software are quite expensive but even more expensive is the standardization of cadastral data to implement GIS software. Therefore, the reason for not to implement new cadastral systems technology in many countries of the world, including even the developed countries of Europe is the lack of a sense the necessity and advisability of this technology use, but lack the financial resources to achieve this determinant. As the good practice examples show in Germany [33], Norway [34] and Spain [35] funding the cadastre for existing databases modernization to the land administration systems, allowed to obtain in a rapid pace self-sufficient modern cadastral system, bringing revenue to the State.

\section{Conclusions}

The analyzed concepts relate closely to the assumptions of "Cadastre 2014" so that they make this report as a basic reference document for guiding the processes of cadastral systems modernization. These concepts are complementary creating a new global nature of the future cadastres. They agree on the need for the development of cadastre through the use of modern information technologies. Can also notice that there is a need to implement the standard version of software and data processing, and cadastral data sharing through modern ICT infrastructure network (INTERNET). Standardization is essential for most of the proposals, but reaching further, it will be necessary to harmonize the ontology, which means foundation on which will be built a modern cadastre. The fundamental concept is therefore "Cadastre 2014".

The direction of cadastre development indicates to achieve in the first place benchmarks of "Cadastre 2014" and then "Cadastre 2.0" and assumes ultimately achieve the following benchmarks in the aspect of cadastral system technology:

- digital technology supply data (electronic data transmission), storing, updating and sharing;

- processes automation of data collection and updating;

- the software should allow integration of graphic and descriptive data, and imaging any content in any format (2D, 3D, 4D);

- inclusion of GIS technology to share cadastral data in spatial information infrastructure (SDI) and for open spatial analysis;

- mobile cadastre through mobile devices and desktop (such as mobile phones, tablets, notebooks and other);

- cadastre in Cloud Computing. 


\section{References}

[1] Dawidowicz, A.; Źróbek, R. 2011. The evolving role of Polish cadastral system in the light of the International Federation of Surveyors assumptions. (only in Polish "Ewolucja potencjału systemu katastru nieruchomości w Polsce w świetle założeń Międzynarodowej Federacji Geodetów (FIG)", Journal of the Polish Real Estate Scientific Socjety 19(4): 55-70.

[2] Williamson, I. 2008. Using Cadastres to Support Sustainable Development, in Spanish IX National Congress of Surveying Engineers TOP-CART 2008 in Valencia, Spain 18-21 February 2008

[3] Rajabifard, A.; Binns, A.; Williamson, I. 2005. Creating an enabling platform for the delivery of spatial information, in Proceedings of the Spatial Sciences Institute Biennial Conference, Melbourne, Australia, 12-16 September, 2005.

[4] Bennett, R.; Wallace, J.; Williamson, I. P. 2007. Organizing land information for sustainable land administration, Journal of Land Use Policy (25): $126-138$

[5] Kaufmann, J.; Steudler, D. 1998. Cadastre 2014 a vision for a future cadastral system, in FIG - Commission 7 Working group (1994-1998) “Vision Cadastre"

[6] Kaufmann, J.; Kaul, Ch. 2004. Assessment of the Core Cadastral Domain Model from a Cadastre 2014 Point of View, in Proceedings of the workshop standardisation in the cadastral domain, Bamberg, Germany, 9-10 December 2004, FIG, Denmark.

[7] van der Molen, P. 2003. The Future Cadastres - Cadastres after 2014, in Proceedings of the FIG Working Week and 125th Anniversary of FIG, Paris, France, 13-17 April 2003.

[8] Lemmen, C. H.; Oosterom van, P.; Zevenbergen, J.; Quak, W.; Molen van der, P. 2003, in Further Progress in the Development of the Core Cadastral Domain Model. FIG Working Week, Paris, France, 13-17 April 2003.

[9] Lemmen, C. H.; Oosterom van, P. 2006. Version 1.0 of the FIG Core Cadastral Domain Model, in XXIII FIG Congress. Munich, Germany, October 8-13, 2006.

[10] Oosterom van, P.; Lemmen, Ch.; Ingvarsson, T.; Molen van der, P.; Ploeger, H.; Quak, W.; Stoter, J.; Zevenbergen, J. 2006. The core cadastral domain model. Science Direct, Computers, Environment and Urban Systems 30: 627-660. http://dx.doi.org/10.1016/j.compenvurbsys.2005.12.002

[11] Hespanha, J.; Bennekom-Minnema van, J.; Oosterom, P.; Lemmen, C. H. 2008. The Model Driven Architecture Approach Applied to the Land Administration Domain Model Version 1.1 - with Focus on Constraints Specified in the Object Constraint Language. FIG Working Week 2008 Stockholm, Sweden, 14-19 June 2008.

[12] UNECE 2000. Study on key aspects on land registration and cadastral legislation, HM Land Registry, London, United Kingdom, May 2000.

[13] UNECE 2005a. Guidelines on real property units and identifiers. Geneva, 2005.

[14] UNECE 2005b. Land administration in the UNECE region. Development trends and main principles. Geneva 2005.

[15] Laarakker, P. 2008. EuroGeographics' Vision on Cadastre and Land Registration in Europe 2012, in FIG Working Week 2008, Integrating Generations, Stockholm, Sweden 14-19 June 2008

[16] Krelle, A.; Rajabifard, A. 2010. Cadastre 2014: New Challenges and Direction, in FIG Congress 2010. Facing the Challenges - Building the Capacity. 11-16 April 2010, Sydney, Australia.

[17] Kalantari, M., Rajabifard, A., Bennett R. 2010. Modern Land Administration; Technical Characteristics. FIG Congress 2010. Facing the Challenges - Building the Capacity. 11-16 April 2010, Sydney, Australia.

[18] Bennett, R.; Rajabifard, A.; Kalantari, M.; Wallace, J.; Williamson, I. 2010. Cadastral Futures: Building a New Vision for the Nature and Role of Cadastres, FIG Congress 2010. Facing the Challenges - Building the Capacity. 11-16 April 2010, Sydney, Australia.

[19] Schernnach, G. 2011. Challenges for the profession in a Cadastre 2.0 world, in Proceedings 3rd Cadastral Congress. November 23-25, 2011, Warsaw, Poland.

[20] Land, N. 2011. Cadastre 2.0 - next generation of cadaster, Presentation on $3^{\text {rd }}$ Cadastral Congress. November 23-25, 2011, Warsaw, Poland

[21] Lagowski, J. 2010. Cloud Computing - What is it?, in Proc. of the XVI Conference PLOUG, October 2010, IBM, Kościelisko, Poland.

[22] Konieczna, J. 2003. Proposed of structure of the multiple functions cadastre information layers (in polish). PhD thesis performed under the supervision of the promoter prof. dr hab. inż. Stanisława Surowca, Olsztyn, Poland.

[23] Hycner, R. 2004. Podstawy katastru (only in polish "Basics of cadastre"). AGH. Kraków, Poland, pp. 292

[24] Hycner, R. 2006. The cadastre and land registry in the aspect of real estate cadastre (only in polish "System ewidencji gruntów i budynków oraz ksiag wieczystych w aspekcie katastru nieruchomości"), in Proceedings of National Conference on Science and Technology on "Aspects of the real estate cadastre", 21-22 June. Educaterrra, Olsztyn, Poland.

[25] Karabin, M. 2005. The concept of model structure cadastral system in Poland on the basis of selected solutions in the European Union The concept of model structure cadastral system in Poland on the basis of selected solutions in the European Union. ( only in polish " The concept of model structure cadastral system in Poland on the basis of selected solutions in the European Union"). PhD thesis performed under the supervision of the promoter Prof. Wojciech Wilkowki, Warszawa, Poland.

[26] Wilkowski, W., Karabin, M., 2006. Cadastre 2020 - a Vision for a Future Cadastral System in Poland, in Proceedings of the XXIII FIG Congress 813 October 2006 Munich, Germany.

[27] Zwirowicz, K. 2006. Finding the degree of relevance of traits criterion cadastre effectiveness (Only in polish „Ustalenie stopnia istotności wyróżników kryterialnych efektywności systemu ewidencji gruntów i budynków”). Przegląd Geodezyjny No 6, Warszawa, pp. 3-9.

[28] Zwirowicz, K. 2008. Method of evaluation the efficiency of the real estate cadastre. (only in polish "Metoda oceny sprawnosici funkcjonowania katastru nieruchomości". UWM. Olsztyn, pp. 111. ISBN 8372995966.

[29] REGULATION OF 17 JANUARY 2013. Rozporządzenie Rady Ministrów z dnia 17 stycznia 2013 w Zintegrowanego Systemu Informacji o Nieruchomościach (Council of Ministers OF 17 JANUARY 2013 on the Integrated Real Estate Information System), (Dz.U. 2013,poz. 249), www.isap.sejm.gov.pl, (in Polish)

[30] Dawidowicz, K. 2013. Impact of different GNSS antenna calibration models on height determination in the ASG-EUPOS network - a case study, Survey Review 45(332): 386-394. http://dx.doi.org/10.1179/1752270613Y.0000000043

[31] DIRECTIVE 2007/2/EC OF THE EUROPEAN PARLIAMENT AND OF THE COUNCIL OF 14 MARCH 2007 establishing an Infrastructure for Spatial Information in the European Community (INSPIRE)

[32] Kwiecień, J. 2006. Trendy rozwojowe GIS (only in polish "GIS Development Trends"). Przegląd Geodezyjny No 6, pp. 12-18, SIGMANOT, Warszawa.

[33] Knoop, H. 2002. The integration of cadastre in Germany, in X Scientific-Technical Conference on the "Real Estate Cadastre", 12 - 14 September 2002, Kalisz, Poland.

[34] Onsrud, H. 2003. Integrating the Cadastre and the Land Register in a Single Organization in Norway, in FIG Working Week and 125th Anniversary of FIG, Paris, France, 13-17 April 2003.

[35] Velasco, A. 2009. The cadastral virtual office and its evolution, in Proceedings of the XI Conference ODGiK nt. "New tasks, new technologies, new organization - not just the INSPIRE", 23-24 April 2009, Elblag, Poland. 